\title{
Minat dan Penggunaan Fintech PayLater Pekerja Urban Pelanggan Traveloka dan GoJek Sebelum dan Selama Pandemi Covid-19 di DKI Jakarta
}

\author{
Gidion P. Adirinekso \\ Program Studi Manajemen Universitas Kristen Krida Wacana \\ Jl. Tanjung Duren Raya No.4 Grogol petamburan, Kota Jakarta Barat, Indonesia \\ gidion.adirinekso@ukrida.ac.id
}

Diterima: 09-02-2021

Disetujui: 16-06-2021

Dipublikasi: 30-06-2021

\begin{abstract}
ABSTRAK
Pandemi Covid-19 melanda Indonesia, dan berdampak salah satunya bagi aktivitas sistem pembayaran. Sistem aplikasi PayLater, berkembang sebagai salah satu metode pembayaran dana talangan dari perusahaan. Dua perusahaan besar, Traveloka dan GoJek menawarkan sistem bayar nanti yang terkait dengan aplikasi mereka. Namun demikian hal yang sama ditawarkan oleh OVO untuk perusahaan yang bekerjasama dengannya. Ketika terjadi pandemi tersebut, apakah akan merubah minat dan penggunaan aplikasi PayLater tersebut? Penelitian ini mencari faktor-faktor yang mempengaruhi minat dan penggunaan PayLater pekerja urban di DKI Jakarta. Berdasarkan Unified Theory Acceptance and Use of Technology generasi kedua (UTAUT2) sebagai landasan teori untuk mencari faktor-faktor tersebut dengan menggunakan PLS-SEM. Analisis Multi-Grup ditambahkan untuk melihat adanya perbedaan dari segi transaksi, jender, tipe generasi, masa pandemi. Terdapat 1201 pekerja kota di survey di Provinsi DKI. Kontribusi penelitian dari sisi analisis multi group, dan berimplikasi praktis bagi perusahaan Traveloka, GoJek dan OVO. Penelitian ini masih bisa dikembangkan dengan mempertimbangkan terjadinya switching behavior pekerja urban ketika muncul fintech baru dari sisi biaya, manfaat, dan waktu tenor. Hal kedua yang belum dilakukan di dalam penelitian ini adalah menggunakan data panel, dimana responden yang sama diamati pada periode sebelum, selama dan sesudah masa.
\end{abstract}

Kata Kunci:

PayLater; UTAUT2; Analisis Multi Grup.

\begin{abstract}
The Covid-19 pandemic hit Indonesia, and one of the impacts on payment system activities. The PayLater application system develops as a method of bailout payment from companies. Two large companies, Traveloka and GoJek, offer a later payment system associated with their application. However, OVO provided the same thing for companies that work with them. When a pandemic occurs, will it change the interest and use of the PayLater application? This study looks for factors that influence the part and use of PayLater for urban workers in DKI Jakarta. Based on the second generation of Unified Theory Acceptance and Use of Technology (UTAUT2) as a theoretical basis for finding these factors using PLS-SEM. The multi-group analysis shows any differences in terms of transactions, gender, type of generation during the pandemic. There were 1201 urban workers surveyed in DKI Province. The research contribution is in multi-group analysis and has practical implications for Traveloka, GoJek, and OVO companies. Another study should consider cost switching for urban workers when new fintech emerges in terms of costs, benefits, and tenor times. We can use panel data, where the same respondents are observed in the period before, during, and after the period.
\end{abstract}

Keywords:

PayLater; UTAUT2; Multi Group Analysis. 


\section{PENDAHULUAN}

Di Indonesia, Traveloka dan GoJek mampu menciptakan bisnis start up yang inovatif dan kreatif. PayLater adalah salah satu inovasinya. Fasilitas pembayaran ini memungkinkan konsumen membayar dengan mencicil, pembelian jasa transportasi dan akomodasi. Inovasi PayLater apakah akan diminati para pekerja urban ketika bertransaksi di Traveloka dan GoJek? Persoalannya apakah pekerja urban tersebut berminat menggunakannya?

Dalam perkembangannya fasilitas PayLater ini juga ditawarkan oleh perusahaan pembiayaan lainnya, misalnya OVO. Tabel 1 berisi perbandingan PayLater Traveloka, GoJek dan OVO.

Tabel 1. Perbandingan PayLater

\begin{tabular}{llll}
\hline \multicolumn{1}{c}{ Nama } & Bunga & Tenor & Limit \\
\hline Traveloka PayLater & $2,14-4,78 \%$ & $1-12$ bulan & Rp 50 juta \\
GoJek PayLater & Rp 25 ribu & Tiap akhir bulan & Rp 500 ribu \\
OVO PayLater & $2,9 \%$ & $3-12$ bulan & Rp 10 juta \\
\hline
\end{tabular}

Sumber: Survei, 2020

Banyak faktor mempengaruhi minat menggunakan PayLater, baik sebelum dan selama masa pandemi Covid-19. Berbagai faktor yang mempengaruhi minat atas aplikasi fintech dan perilakunya telah dikembangkan oleh (Venkatesh, Morris, Davis, \& Davis, 2003) dan diperbaharui oleh (Venkatesh, Thong, \& Xu, 2012).

Pandemi Covid-19 yang menerpa dunia, mungkin akan berdampak pada penerimaan dan penggunaan PayLater di Traveloka dan GoJek dibandingkan masa sebelumnya. Pandemi Covid-19 memaksa pekerja urban semakin berhati-hati menggunakan jasa transportasi umum. Faktor yang mempengaruhi minat menggunakan PayLater mungkin akan berbeda bagi pekerja pria dan wanita karena kebiasaan (habit) yang berbeda. Pekerja urban lintas generasi memiliki motivasi hedonis, harapan, upaya dan lingkungan sosial berbeda-beda terhadap penerimaan dan penggunaan PayLater dalam pembayaran.

Penelitian ini merujuk pada model evaluasi penerimaan dan penggunaan suatu aplikasi teknologi yang dikembangkan oleh Venkatesh et.al (2012), sebagai perbaikan model sebelumnya (Venkatesh et.al, 2003). Apakah ada pengaruh faktor-faktor penerimaan dan penggunaan PayLater bagi pekerja urban ? Apakah ada perbedaan pengaruh faktor-faktor tersebut sebelum dan selama masa pandemi, antara pria dan wanita, antar generasi dan pengalaman pekerja urban terhadap minat menggunakan PayLater?

Model UTAUT2 sebagai modifikasi dari model UTAUT (Nanggala, 2020) yang dikembangkan oleh Venkatesh dkk (2003). Model ini memaparkan pengaruh langsung ekspektasi kinerja, ekspektasi usaha, dan pengaruh sosial terhadap niat perilaku (Ramos, 2016) dan dampak dari kondisi fasilitasi dan niat perilaku terhadap perilaku pengguna. Lebih lanjut, Venkatesh dkk. (2012) menjelaskan bahwa modifikasi utama UTAUT untuk merumuskan model UTAUT2 adalah mempelajari penerimaan dan penggunaan teknologi, kemudian menyesuaikannya dalam konteks penggunaan oleh konsumen. Venkatesh dkk (2012) menambahkan tiga konstruk tambahan pada model UTAUT2 yaitu Hedonic 
Motivation, Price Value, dan Habit, serta tiga variabel moderator yaitu Umur, Jenis Kelamin, dan Pengalaman. Dalam penelitian ini, variabel nilai harga tidak digunakan seperti oleh Venkatesh (2012).

Penelitian dengan menggunakan model UTAUT2 khususnya aplikasi PayLater yang disediakan oleh perusahaan sendiri dan oleh pihak ketiga telah dilakukan oleh Adirinekso, Purba dan Budiono (Adirinekso, Purba, \& Budiono, 2020). Namun, penelitiannya tidak mengamati persoalan pandemic Covid-19 yang melanda di Indonesia.

Kim dan Lee (Kim \& Lee, 2010) melakukan pengujian empiris terhadap faktor-faktor kepemilikan kas, kemudian pengaruh minat dalam menggunakan pembayaran mobile. Persepsi kemudahan penggunaan dan persepsi kegunaan sebagai prediktor kuat dari niat menggunakan mpayment (Rajagukguk, Samosir, Purba, Budiono, \& Adirinekso, 2020).

Penelitian penggunaan teknologi penerbangan swalayan dengan menggunakan model UTAUT2 oleh Kim dan Kim (Kim H.-Y. K.-S., 2018) menyatakan bahwa ekspektasi kinerja dan motif hedonis mempengaruhi kepercayaan awal konsumen, kemudian mempengaruhi minat dalam menggunakannya. Penelitian Mukminin, Rachman dan Wahyudi (Mukminin, Rachman, \& Wahyudi, 2019) tentang PayLater di Traveloka memperlihatkan bahwa kinerja dan harapan usaha, pengaruh sosial, dan kondisi fasilitasi mempengaruhi niat berperilaku. Model yang digunakan adalah UTAUT dari Verkantesh (2003), dan menggunakan regresi linier berganda, yang memiliki keterbatasan untuk digunakan dalam penelitian ini (Rajagukguk, Samosir, Purba, Budiono, \& Adirinekso, 2020).

Nanggala (2020) mensurvei penggunaan fintech pembayaran dengan pendekatan Modified Technology Acceptance Model untuk persepsi keamanan web dari niat menggunakan fintech. Hasil penelitian menunjukkan bahwa perceived security web mempengaruhi sikap terhadap fintech, kemudian niat menggunakan fintech. Sedangkan Nuriska dkk (Nuriska, Asakdiyah, \& Setyawan, 2018) meneliti faktor-faktor yang mempengaruhi niat berperilaku dalam menggunakan GoPay dengan modifikasi model UTAUT2 di Yogyakarta. Hasil penelitian menunjukkan bahwa Kebiasaan, Kondisi Fasilitas, dan Nilai Harga berpengaruh signifikan terhadap minat dalam menggunakan GoPay. Hasil ini juga didukung oleh penelitian Siahaan dan Legowo (Siahaan \& Legowo, 2019).

Shao \& Siponen (Shao \& Siponen, 2011) menunjukkan bahwa perspektif ekonomi harus diperhatikan dalam melakukan analisis penerimaan konsumen dan penggunaan teknologi informasi serta efektivitas penerapan dan lebih produktif (Aileen, Widjaja, Purba, \& G, 2019), Purba, Samuel, \& Purba, 2020). Secara empiris mereka memperluas UTAUT2 dengan teori konsumsi yang ternyata memberikan penjelasan yang lebih baik daripada model UTAUT2. Shara dan Widodo (Shara \& Widodo, 2018) melakukan penelitian di Bandung dengan model UTAUT. Hasil penelitian menunjukkan bahwa tidak terdapat pengaruh ekspektasi kinerja terhadap sikap penggunaan smartphone, dan kondisi fasilitas tidak berpengaruh terhadap penerimaan penggunaan smartphone (Adirinekso, Purba, Budiono, \& Rajagukguk, 2020). 


\section{METODE RISET}

Dalam penelitian ini penulis menggunakan pelanggan Traveloka dan GoJek khususnya pekerja urban di DKI Jakarta. Mereka melakukan transaksi online di Traveloka dan GoJek. Metode convenience sampling digunakan untuk memilih sampel. Semua kuesioner yang berhubungan dengan variabel utama menggunakan pertanyaan tertutup dengan skala likert lima (Venkatesh, 2012). Skala likert dapat mengukur sikap, pendapat, dan persepsi seseorang atau sekelompok orang tentang suatu gejala atau fenomena (Djaali, 2008).

Penelitian ini menggunakan variabel dan indikator yang dikembangkan oleh Venkatesh (2003, 2012), dengan pernyataan yang disesuaikan dengan obyek penelitian, yaitu pembayaran di Traveloka dan GoJek. Untuk keperluan penulisan makalah ini, maka penulisan PayLater Traveloka, GoJek PayLater dan OVO PayLater, cukup dituliskan dengan PayLater. Namun dalam kuesioner yang diedarkan tetap dituliskan ketiga-tiganya. Variabel Performance Expectancy terdiri dari beberapa indikator: PE1: Menurut saya PayLater berguna untuk bertransaksi; PE2: Menggunakan PayLater meningkatkan peluang mendapatkan sesuatu yang penting bagi saya; PE3: Menggunakan PayLater membantu saya transaksi lebih cepat; PE4: PayLater meningkatkan efektivitas transaksi; PE5: PayLater meningkatkan efisiensi bertransaksi. Variabel Effort Expectancy: EE1: Mempelajari penggunaan PayLater mudah bagi saya; EE2: Interaksi penggunaan PayLater jelas dan dimengerti; EE3: Saya merasa mudah menggunakan PayLater dalam bertransaksi; EE4: Fasilitas PayLater memudahkan saya bertransaksi. Variabel Social Influence: SI1: Orang yang saya anggap penting menganggap saya harus menggunakan PayLater; SI2: Orang yang mempengaruhi perilaku saya berpikir bahwa saya harus menggunakan PayLater; SI3: Orang yang berpandangan bahwa saya memprioritaskan penggunaan PayLater dalam transaksi. Variabel Facilitating Conditions: FC1: Saya memiliki sumber daya yang diperlukan untuk menggunakan PayLater; FC2: Saya memiliki pengetahuan yang diperlukan untuk menggunakan PayLater; FC3: PayLater sangat cocok untuk transaksi online; FC4: Saya akan mudah mendapatkan bantuan dari pihak lain jika saya kesulitan menggunakan PayLater. Variabel Hedonic Motives: HM1: Bagi saya menyenangkan menggunakan PayLater; HM2: Saya senang menggunakan fasilitas PayLater; HM3: Bagi saya pakai PayLater bisa meningkatkan transaksi. Variabel Habit: HT1: Pakai PayLater sudah menjadi kebiasaan saya bertransaksi online; HT2: Saya kecanduan pakai PayLater; HT3: Saya harus menggunakan PayLater saat bertransaksi; HT4: Menggunakan PayLater sudah menjadi kebiasaan yang wajar dalam bertransaksi. Variabel PayLater Intention: BI1: Saya cenderung terus menggunakan PayLater di masa mendatang; BI2: Saya akan selalu berusaha menggunakan PayLater dalam transaksi online saya sehari-hari; BI3: Saya berencana melanjutkan penggunaan PayLater dalam transaksi online lebih sering;.

Metode analisis dalam penelitian ini menggunakan PLS-SEM (Henseler, J; Ringle, C. M; Sinkovics, R. R , 2009) yang telah diterapkan dalam banyak penelitian pemasaran (McDaniel Jr \& Gates, 2015). Ada 3 pertimbangan menggunakan PLS-SEM, yaitu pertimbangan awal, penilaian model 
pengukuran dan penilaian model structural. Selain aspek asumsi distribusi yang harus diperhatikan, juga kekuatan statistik, dan Godness of Fit, maka untuk pertimbangan sampel dinyatakan bahwa jika populasi penelitian kecil akan membatasi besarnya sampel, misalnya penelitian business-to-business., tetapi PLS-SEM juga bekerja sangat baik dengan ukuran sampel yang besar (Hair, Risher, Sarstedt, \& Ringle, 2019).

Structural Equation Modeling (SEM) saat ini digunakan untuk menutupi kelemahan metode regresi. SEM merupakan evolusi model persamaan regresi berganda yang dikembangkan dari prinsip ekonometri dan digabungkan dengan prinsip psikologi dan sosiologi (Ghozali, 2014). SEM telah muncul sebagai bagian integral dari akademik, manajerial penelitian. Pendekatan indikator dalam penelitian ini adalah pendekatan reflektif, dimana indikator tersebut dapat mencerminkan variabel laten. Model reflektif menunjukkan bahwa setiap indikator merupakan pengukuran kesalahan yang dikenakan pada variabel tersembunyi (Anderson \& Gerbing, 1988).

SEM dengan Analisis Multi Grup menggunakan Partial Least Square (PLS) yang terdiri dari tiga komponen yaitu model struktural, model pengukuran, dan skema pembobotan (Monecke \& Leisch, 2012). SmartPLS 3.2.8 merupakan software yang menyajikan tampilan grafik dari variance-based dan factor-based SEM dengan menggunakan metode partial least squares dan factor-based kepada penggunanya (Wong, 2013).

Uji Outer model dilakukan untuk memastikan pengukuran yang digunakan sesuai dengan ukuran (validitas konvergen dan diskriminan serta uji reliabel). Dalam pendekatan PLS-SEM, suatu pengukuran memenuhi validitas konvergen jika memenuhi: Parameter faktor pembebanan>0,7; Parameter Average Variance Extracted (AVE)> 0,5; Parameter komunalitas> 0,5. (Hair, Hult, Ringle, $\&$ Sarstedt, 2017). Nilai AVE sebagai pengukuran validitas diskriminan lebih tinggi dari nilai korelasi kuadrat (Hair, Black, Babin, \& Anderson, 2014). Secara praktis, pengukuran uji validitas diskriminan dirumuskan sebagai berikut: Parameter root AVE dan korelasi variabel laten> asosiasi variabel potensial. Parameter cross loading> 0,7 dalam satu variabel (Vinzi, 2010).

Pengujian reliabilitas dapat menggunakan dua metode. Pertama, alpha Cronbach dan reliabilitas komposit. Cronbach's alpha mengukur batas bawah nilai reliabilitas konstruk, sedangkan reliabilitas komposit mengukur nilai aktual reliabilitas konstruk. Nilai alpha atau composite reliability lebih tinggi dari 0,7 meskipun besarnya 0,6 masih dapat diterima Hair, dkk, (Hair, Black, Babin, \& Anderson, 2014).

Tes Inner Model dilakukan untuk menguji hubungan antara konstruksi laten. Ada beberapa pengujian model struktural a) R Square> 0.67 (kuat), 0.33 (sedang), 0.19 (lemah) (Abdillah \& Jogiyanto, 2009); b) Perkiraan untuk path coefficient yang dilakukan prosedur Bootstrap; c) Prediction Relevance (Q Square) atau disebut juga Stone-Geisser's. d). Q Square jika nilai yang diperoleh adalah 0,02 (kecil), 0,15 (sedang) dan 0,35 (besar) (Vincenzo, Chin, Henseler, \& Wang, 2010). 
Pengujian hipotesis. Untuk menguji hipotesis akan dianalisis $p$ value dari uji SEM PLS. Untuk menguji hipotesis ini, nilai $\mathrm{P}$ harus lebih besar dari 0 , dengan tingkat signifikansi 1-95\% atau 0,05. Dalam uji P-value, untuk menguji hipotesis sering digunakan $\mathrm{P}<0,05$ daripada $\mathrm{P} \leq 0,05$ (Kock \& Hadaya, 2018).

\section{HASIL PENELITIAN DAN PEMBAHASAN}

Profil responden di dalam penelitian ini disajikan dalam bentuk tabel. Profil dibuat berdasarkan gender pekerja urban, kategori generasi pekerja urban, pemakaian fasilitas PayLater secara langsung dan tidak langsung, tinggi rendahnya pengalaman melakukan transaksi dengan PayLater dan pekerja urban yang melakukan transaksi sebelum dan sesudah pandemi Covid-19.

Tabel 2. Komposisi Jender dan Generasi

\begin{tabular}{|c|c|c|c|c|c|}
\hline Kota & Pria & Wanita & Gen_Y & Gen_Z & Total \\
\hline \multirow[t]{2}{*}{ Jakarta Pusat } & 100 & 126 & 172 & 54 & 226 \\
\hline & $8 \%$ & $10 \%$ & $14 \%$ & $4 \%$ & $19 \%$ \\
\hline \multirow[t]{2}{*}{ Jakarta Barat } & 136 & 145 & 219 & 62 & 281 \\
\hline & $11 \%$ & $12 \%$ & $18 \%$ & $5 \%$ & $23 \%$ \\
\hline \multirow[t]{2}{*}{ Jakarta Selatan } & 132 & 140 & 196 & 76 & 272 \\
\hline & $11 \%$ & $12 \%$ & $16 \%$ & $6 \%$ & $23 \%$ \\
\hline \multirow[t]{2}{*}{ Jakarta Timur } & 124 & 114 & 173 & 65 & 238 \\
\hline & $10 \%$ & $9 \%$ & $14 \%$ & $5 \%$ & $20 \%$ \\
\hline \multirow[t]{2}{*}{ Jakarta Utara } & 76 & 108 & 135 & 49 & 184 \\
\hline & $6 \%$ & $9 \%$ & $11 \%$ & $4 \%$ & $15 \%$ \\
\hline \multirow[t]{2}{*}{ Total } & 568 & 633 & 895 & 306 & 1201 \\
\hline & $47 \%$ & $53 \%$ & $75 \%$ & $25 \%$ & $100 \%$ \\
\hline
\end{tabular}

Berdasarkan tabel 2, maka komposisi pekerja urban yang menjadi responden penelitian relatif seimbang menurut gender, atau kota di Provinsi DKI. Namun demikian untuk tingkat generasi pekerja urban, masih didominasi oleh generasi Y dibandingkan generasi $\mathrm{Z}$.

Hal yang cukup menarik dari profil pekerja urban yang menjadi responden relatif merata dalam menggunakan fasilitas PayLater dari Traveloka, GoJek atau OVO. Jika dipisahkan secara sederhana, Sebagian besar (70\%) menggunakan fasilitas PayLater yang diberikan langsung oleh Traveloka dan Go Jek. Sisanya menggunakan fasilitas OVO PayLater untuk bertransaksi di Traveloka dan GoJek, seperti ditunjukkan di Tabel 3.

Para pekerja urban di DKI melakukan transaksi yang bervariasi antara yang tinggi dan yang rendah di setiap kota (Tabel 4). Secara keseluruhan kota Jakarta Barat di posisi tertinggi, kemudian diikuti Jakarta Selatan, Jakarta Timur, Jakarta Pusat dan Jakarta Utara. Pekerja urban yang melakukan transaksi lebih dari 24 kali dalam 3 bulan terakhir saat dikategorikan tinggi dalam bertransaksi menggunakan fasilitas PayLater 
Tabel 3: Komposisi Pengguna PayLater

\begin{tabular}{lllll}
\hline Kota & Traveloka & Go Jek & OVO & Total \\
\hline Jakarta Pusat & 76 & 79 & 71 & 226 \\
& $6 \%$ & $7 \%$ & $6 \%$ & $19 \%$ \\
Jakarta Barat & 98 & 100 & 83 & 281 \\
& $8 \%$ & $8 \%$ & $7 \%$ & $23 \%$ \\
Jakarta Selatan & 100 & 93 & 79 & 272 \\
& $8 \%$ & $8 \%$ & $7 \%$ & $23 \%$ \\
Jakarta Timur & 87 & 86 & 65 & 238 \\
& $7 \%$ & $7 \%$ & $5 \%$ & $20 \%$ \\
Jakarta Utara & 58 & 60 & 66 & 184 \\
& $5 \%$ & $5 \%$ & $5 \%$ & $15 \%$ \\
\hline Total & 419 & 418 & 364 & 1201 \\
& $35 \%$ & $35 \%$ & $30 \%$ & $100 \%$ \\
\hline
\end{tabular}

Sumber: Survei, 2020

Di tabel 5 diperlihatkan adanya kestabilan jumlah pekerja urban dalam bertransaksi sebelum masa dan sesudah pandemi Covid-19 dengan menggunakan PayLater. Apakah hal ini akan berimplikasi pada tidak ada perbedaan faktor-faktor yang menjelaskan minat dan frekuensi penggunaan antara sebelum dan selama masa pandemi Covid19.

Tabel 4. Pengalaman Bertransaksi

\begin{tabular}{cccc}
\hline Kota & Tinggi & Rendah & Total \\
\hline Jakarta Pusat & 108 & 118 & 226 \\
& $9 \%$ & $10 \%$ & $19 \%$ \\
Jakarta Barat & 134 & 147 & 281 \\
& $11 \%$ & $12 \%$ & $23 \%$ \\
Jakarta Selatan & 146 & 126 & 272 \\
& $12 \%$ & $10 \%$ & $23 \%$ \\
Jakarta Timur & 119 & 119 & 238 \\
& $10 \%$ & $10 \%$ & $20 \%$ \\
Jakarta Utara & 105 & 79 & 184 \\
& $9 \%$ & $7 \%$ & $15 \%$ \\
\hline Total & 612 & 589 & 1201 \\
& $51 \%$ & $49 \%$ & $100 \%$ \\
\hline
\end{tabular}

Sumber: Survei, 2020

Untuk itu perlu dilihat kaitan transaksi sebelum dan selama masa Covid-19 dengan tinggi rendahnya transaksi. Hal ini disajikan di tabel 5.

Tabel 5. Crosstab Pandemi dan Frekuensi

\begin{tabular}{cccc}
\hline \multirow{2}{*}{ Pandemik } & \multicolumn{3}{c}{ Frekuensi Penggunaan } \\
\cline { 2 - 4 } Sebelum & Tinggi & Rendah & Total \\
& 427 & 195 & 622 \\
Selama & $36 \%$ & $16 \%$ & $52 \%$ \\
& 310 & 169 & 579 \\
Total & 837 & 364 & 1201 \\
& $70 \%$ & $30 \%$ & $100 \%$ \\
\hline \multicolumn{4}{c}{ Sumber: Survei, 2020. }
\end{tabular}




\begin{tabular}{llll}
\multicolumn{4}{c}{ Tabel 6. Komposisi Transaksi } \\
\hline Kota & Sebelum & Selama & Total \\
\hline Jakarta Pusat & 112 & 114 & 226 \\
& $9 \%$ & $9 \%$ & $19 \%$ \\
Jakarta Barat & 145 & 136 & 281 \\
& $12 \%$ & $11 \%$ & $23 \%$ \\
Jakarta Selatan & 144 & 128 & 272 \\
& $12 \%$ & $11 \%$ & $23 \%$ \\
Jakarta Timur & 117 & 121 & 238 \\
& $10 \%$ & $10 \%$ & $20 \%$ \\
Jakarta Utara & 104 & 80 & 184 \\
& $9 \%$ & $7 \%$ & $15 \%$ \\
\hline Total & 622 & 579 & 1201 \\
& $52 \%$ & $48 \%$ & $100 \%$ \\
\hline \multicolumn{4}{c}{ Sumber: Survei, 2020.} \\
\end{tabular}

Melihat kepada proporsi yang diperlihatkan di tabel 6, maka bisa diperkirakan bahwa tidak ada perbedaan yang signifikan dalam hal penggunaan PayLater di masa sebelum dan selama pandemi Covid19. Hal ini mungkin akan berimplikasi pada hasil pembuktian model dalam penelitian ini.

Berdasarkan pengujian atas model seperti ditunjukkan dalam Tabel 7, terlihat bahwa semua kriteria yang diperlukan untuk mengukur baik tidaknya model telah terpenuhi. Berdasarkan hasil estimasi model PLS SEM pada tabel 8, diperoleh beberapa informasi. Pertama, bahwa pekerja di daerah urban di Propinsi DKI memperlihatkan sebagian besar perilaku yang sesuai dengan teori yang dikembangkan oleh Vekantesh (2012).

Effort espectancy mempengaruhi penggunaan PayLater dalam bertransaksi, baik di Traveloka, GoJek, maupun OVO. Hal ini dikarenakan pekerja urban cukup mudah belajar menggunakan aplikasi PayLater, maupun interaksi yang dijalani selama menggunakannya jelas dan dapat dipahami.

Tabel 7: Measurement Model

\begin{tabular}{|c|c|c|c|c|c|}
\hline Variables & Indicators & Outer Loadings $^{\text {a }}$ & $\mathbf{A V E}^{\mathbf{b}}$ & $\mathbf{C R}^{\mathbf{c}}$ & rho_A \\
\hline \multirow{3}{*}{ Effort_Expectation } & EE1 & 0.880 & 0.714 & 0.833 & 0.722 \\
\hline & EE2 & 0.809 & & & \\
\hline & FC2 & 0.805 & 0.726 & 0.888 & 0.817 \\
\hline \multirow{2}{*}{ Facilitating_Conditions } & FC3 & 0.879 & & & \\
\hline & FC4 & 0.869 & & & \\
\hline \multirow[t]{2}{*}{ Freq.of Use } & $\mathrm{FU}$ & 1.000 & 1.000 & 1.000 & 1.000 \\
\hline & HT2 & 0.834 & 0.730 & 0.890 & 0.821 \\
\hline \multirow{2}{*}{ Habit } & HT3 & 0.869 & & & \\
\hline & HT4 & 0.861 & & & \\
\hline \multirow{2}{*}{ Hedonic Motives } & HM1 & 0.899 & 0.757 & 0.861 & 0.703 \\
\hline & HM3 & 0.840 & & & \\
\hline \multirow{2}{*}{ PayLater_Intention } & PI1_ & 0.918 & 0.835 & 0.910 & 0.804 \\
\hline & $\mathrm{PI} 2$ & 0.909 & & & \\
\hline \multirow{2}{*}{ Performance Expectation } & PE3 & 0.854 & 0.691 & 0.870 & 0.798 \\
\hline & PE4 & 0.792 & & & \\
\hline \multirow{2}{*}{ Social_Influence } & SI1 & 0.987 & 0.727 & 0.838 & 2.130 \\
\hline & SI2 & 0.693 & & & \\
\hline
\end{tabular}


Catatan:

Indikator yang dihilangkan karena nilainya dibawah 0.5 yaitu EE3, EE4, FC1, FC2, HM2, HT1, PE1, SI3, P13

a.Semua item loading $>0.5$ mengindikasikan reliabilitas indicator (Hulland, 1999, p 198)

b.Semua nilai Average Variance Extracted (AVE) > 0.5 mengindikasikan Convergent Reliability (Bagozzi dan

Yi (1988); Fornel dan Larcker (1981).

c. Semua nilai Composite Reliability (CR) > 0.7 mengindikasikan konsistensi internal (Gefen et al, 2000)

d. Semua nilai Cronbach Alpha > 0.7 mengindikasikan reliabilitas indicator yang dipakai (Nunnally, 1978).

Faktor facilitating condition memperlihatkan bahwa pekerja urban memiliki pengetahuan menggunakan PayLater, kesesuaian antara teknologi yang dipakai dengan PayLater, serta dimungkinkannya bantuan dari pihak lain ketika mengalami kesulitan dalam menggunakan aplikasi PayLater. Habit, sebagai salah satu faktor yang menjelaskan minat menggunakan aplikasi PayLater ditunjukkan oleh beberapa hal.

Tabel 8. Path Coefficient

\begin{tabular}{ccc}
\hline & T Statistics $(|\mathbf{O} / \mathbf{S T D E V}|)$ & P Values \\
\hline Effort_Expectation -> PayLater_Intention_ & 2.527 & 0.012 \\
Facilitating_Conditions -> Frequency_of Use & 3.368 & 0.001 \\
Facilitating_Conditions -> PayLater_Intention_ & 5.918 & 0.000 \\
Habit_-> Frequency_of Use & 1.388 & 0.166 \\
Habit_-> PayLater_Intention_ & 22.024 & 0.000 \\
Hedonic_Motives -> PayLater_Intention_ & 2.419 & 0.016 \\
PayLater_Intention_-> Frequency_of Use & 1.275 & 0.203 \\
Performance_Expectation -> PayLater_Intention_ & 3.215 & 0.001 \\
Social_Influence -> PayLater_Intention_ & 1.579 & 0.115 \\
\hline
\end{tabular}

Kebanyakan pekerja urban ketagihan menggunakan PayLater, ada semacam keharusan untuk selalu menggunakan PayLater, dan bahkan ada keinginan untuk meningkatkan frekuensi menggunakan PayLater. Kebiasaan pekerja urban di daerah perkotaan itulah yang menjadi salah satu faktor mendorong minat menggunakan aplikasi PayLater yang ditawarkan oleh Traveloka, GoJek dan OVO.

Disamping itu, hedonic motives mendorong pekerja urban untuk menggunakan aplikasi PayLater. Hal ini dikarenakan mereka merasakan kegembiraan di dalam menggunakan PayLater, dan utamanya juga sangat menghibur para pekerja urban tersebut. Kedua hal ini mendorong pekerja urban untuk menggunakan aplikasi PayLater tersebut. Namun demikian faktor atau pengaruh lingkungan sosial (social influence) tidak terbukti ikut berperan mendorong minat pekerja urban. Dalam benak pekerja tersebut, jika orang lain yang mereka anggap penting menjadi pemicu untuk menggunakan PayLater. Dan hal kedua adalah opini dari rekan yang dinilai penting bagi pekerja urban untuk menggunakan PayLater tersebut. Kedua hal ini tidak cukup menjadi alasan, mengapa faktor lingkungan sosial berperan penting terhadap minat pekerja urban menggunakan aplikasi PayLater tersebut.

Faktor harapan atas kinerja (performance expectancy) dengan menggunakan PayLater juga menjadi pendorong bagi pekerja urban untuk berminat dalam menggunakan PayLater, Persepsi pekerja urban itu sederhana, yaitu apakah penggunaan PayLater bisa meningkatkan produktivitas mereka, dan dapat menyelesaikan pekerjaannya lebih cepat dengan menggunakan PayLater. Terpenuhinya harapan ini, menjadi penjelas bagaimana performance expectancy mempengaruhi minat pekerja urban. 
Di dalam penelitian ini, ternyata tidak terkonfirmasi pengaruh minat menggunakan aplikasi PayLater terhadap frekuensi penggunaan PayLater. Artinya kalaupun minat pekerja urban meningkat belum dapat dipastikan bahwa mereka akan meningkatkan frekuensi menggunakan aplikasi PayLater tersebut. Hal ini bersesuaian dengan profil responden yang mengaitkan pandemi dan frekuensi penggunaan aplikasi PayLater yang tidak berubah polanya antara sebelum dan selama pandemi Covid19.

Semakin meningkat tidaknya penggunaan PayLater di Traveloka, GoJek dan OVO ternyata tidak di dukung oleh habit dari pekerja urban. Namun justru facilitating conditions yang menjadi faktor penting bagi pekerja urban meningkatkan penggunaan aplikasi PayLater tersebut. Bekal pengetahuan, kompatibilitas aplikasi, dan kemudahan mendapatkan bantuan pihak lain menjadi pendorong penggunaan aplikasi PayLater.

Studi ini kemudian melakukan analisis multi-group terkait pandemi covid19, tipe generasi, jender, serta tinggi rendahnya pengalaman bertransaksi konsumen.

Tabel 9. MGA Pengalaman Transaksi

\begin{tabular}{cccc}
\hline Pengalaman Transaksi Tinggi dan Rendah & Path Coefficients & t-Value & p-Value \\
\hline Effort_Expectation -> PayLater_Intention_ & 0.056 & 0.926 & 0.355 \\
Facilitating_Conditions -> Frequency_of Use & 0.040 & 0.669 & 0.504 \\
Facilitating_Conditions -> PayLater_Intention_ & -0.057 & 1.198 & 0.231 \\
Habit_-> Frequency_of Use & -0.041 & 0.553 & 0.580 \\
Habit_-> PayLater_Intention_ & -0.042 & 0.787 & 0.431 \\
Hedonic_Motives -> PayLater_Intention_- & 0.086 & 1.294 & 0.196 \\
PayLater_Intention_-> Frequency_of Use & $\mathbf{0 . 1 4 9}$ & $\mathbf{2 . 0 9 0}$ & $\mathbf{0 . 0 3 7}$ \\
Performance_Expectation -> PayLater_Intention_ & $\mathbf{- 0 . 1 3 3}$ & $\mathbf{2 . 3 8 3}$ & $\mathbf{0 . 0 1 7}$ \\
Social_Influence -> PayLater_Intention_- & -0.074 & 1.167 & 0.244 \\
\hline
\end{tabular}

Sumber: Survei, 2020

Tabel 9 memperlihatkan adanya perbedaan pengaruh minat menggunakan aplikasi PayLater terhadap frekuensi penggunaannya. Mereka yang melakukan transaksi tinggi akan cenderung meningkatkan penggunaan aplikasi PayLaternya. Di sisi lain, ada perbedaan pengaruh performance expectancy terhadap minat menggunakan aplikasi PayLater. Mereka yang bertransaksi tinggi cenderung memberikan kontribusi lebih rendah terhadap minat menggunakan aplikasi PayLater. Hal ini bisa dipahami karena mereka yang bertransaksi tinggi bisa menggunakan alternatif pembayaran lainnya.

Untuk analisis multi group berdasarkan gender ternyata tidak ada perbedaan signifikan antara pria dan wanita, Hal ini mengindikasikan bahwa pekerja urban pria dan wanita memiliki kesamaan persepsi atas faktor-faktor yang menjelaskan minat menggunakan aplikasi PayLater maupun frekuensi penggunaannya. Hal yang mirip terjadi untuk MGA antar generasi Y dan generasi Z. Walaupun generasi Y mengalami perkembangan internet dari awal hingga ke tingga saat ini, namun tidak berbeda dengan generasi $\mathrm{Z}$ yang mulai lahir sudah mengenal kemajuan transaksi dengan internet. Hal ini bisa terjadi karena aspek teknologi yang relatif mudah untuk dipelajari lintas generasi. 
Berdasarkan Tabel 10, terlihat bahwa ada perbedaan yang signifikan pengaruh PayLater intention terhadap Frequency of Use aplikasi PayLater. Pengujian ini mengkonfirmasi bahwa sebelum masa pandemi Covid19, pengaruh minat menggunakan aplikasi PayLater lebih besar dibandingkan selama masa pandemi Covid19. Namun demikian tidak ada perbedaan dari faktor-faktor yang mempengaruhi penggunaan PayLater.

Tabel 10. MGA Pandemi

\begin{tabular}{cccc}
\hline MGA Pandemi & Path Coeffi-cients & t-Value & p-Value \\
\hline Effort_Expectation -> PayLater_Intention_ & 0.035 & 0.627 & 0.531 \\
Facilitating_Conditions -> Frequency_of Use & 0.015 & 0.254 & 0.800 \\
Facilitating_Conditions -> PayLater_Intention_- & -0.020 & 0.400 & 0.689 \\
Habit_-> Frequency_of Use & -0.126 & 1.711 & 0.087 \\
Habit_-> PayLater_Intention_ & 0.003 & 0.058 & 0.954 \\
Hedonic_Motives -> PayLater_Intention_ & 0.058 & 0.843 & 0.400 \\
PayLater_Intention_-> Frequency_of Use & 0.165 & $\mathbf{2 . 3 1 4}$ & $\mathbf{0 . 0 2 1}$ \\
Performance_Expectation -> PayLater_Intention_ & -0.015 & 0.279 & 0.780 \\
Social_Influence -> PayLater_Intention_ & -0.080 & 1.260 & 0.208 \\
\hline
\end{tabular}

Sumber: Survei, 2020.

Hal ini bisa dipahami karena selama masa pandemi akan mengurangi minat orang menggunakan fasilitas transportasi yang disediakan melalui Traveloka dan GoJek, dan sudah barang tentu frekuensi penggunaan PayLater OVO

\section{KESIMPULAN DAN SARAN}

Hasil penelitian ini berbeda dengan pembuktian oleh Venkatesh (2012) untuk beberapa variabel independen yang menjelaskan variabel dependen. Perbedaan kedua adalah Multi Group Analysis yang tidak dilakukan di karya Venkatesh. Minat dan penggunaan fintech PayLater oleh pekerja urban di DKI Jakarta dijelaskan oleh ekspektasi kinerja, ekspektasi usaha, kondisi fasilitas, motif hedonis dan kebiasaan. Pengaruh sosial bagi pekerja urban tidak signifikan mempengaruhi minat dan perilaku menggunakannya. Hal ini berbeda dengan penelitian Vekantesh (2012).

Hasil analisis multi-grup memperlihatkan beberapa kesimpulan. Pertama, berdasarkan pengalaman transaksi pekerja urban ada perbedaan pengaruh minat menggunakan PayLater terhadap frekuensi penggunaan antara mereka yang melakukan transaksi tinggi dan rendah. Kedua, ada perbedaan pengaruh performance expectancy terhadap PayLater intention antara pekerja urban bertransaksi tinggi dan rendah. Ketiga, tidak ada perbedaan pengaruh semua variabel independen terhadap variabel dependen di dalam model antara pekerja pria dan wanita urban, serta antara generasi $\mathrm{Y}$ dan generasi Z. Keempat, ada perbedaan pengaruh PayLater intention terhadap frequency of use dari aplikasi PayLater sebelum dan selama pandemi Covid-19 terjadi.

Ada beberapa implikasi dari hasil analisis multigroup. Pertama, pengalaman bertransaksi yang tinggi akan berdampak pada penggunaan aplikasi PayLater lebih intensif, sehingga diharapkan pihak Traveloka atau GoJek bisa memberikan benefit yang lebih besar dari yang ada, agar pelanggan semakin 
terdorong meningkat minat dan penggunaan PayLater yang ditawarkan. Sementara itu bagi penyedia PayLater tidak langsung seperti OVO bisa mengurangi biaya bunga dan atau memperpanjang tenornya, dan jika memungkinkan bisa meningkatkan limit bagi pelanggannya yang bertransaksi di Traveloka atau GoJek. Kedua, masa pandemi sebagai peristiwa force majeure tetap bisa didorong agar terjadi peningkatan minat dan frekuensi penggunaan aplikasi PayLater. Bentuk-bentuk promosi dan manajemen informasi yang semakin memudahkan pelanggan pekerja urban diharapkan bisa meningkatkan transaksi dengan PayLater. Implikasi praktis ketiga dari penelitian ini terkait pengaruh lingkungan sosial bagi pekerja urban yang tidak signifikan terjadi karena era keterbukaan informasi dan kemudahan meniru dan menggunakan teknologi. Traveloka dan GoJek, serta OVO perlu melakukan inovasi dalam pengembangan fintech PayLater yang dibuat, misalnya Traveloka bisa mengembangkan PayLater card tidak hanya dengan BRI namun dengan bank lainnya;

Di samping beberapa implikasi tersebut di atas, penelitian ini masih bisa dikembangkan lebih dalam lagi dengan mempertimbangkan kemungkinan terjadinya switching behavior dari pekerja urban ketika muncul fintech baru yang bersaing dengan PayLater dari sisi biaya, manfaat, dan aspek dimensi waktu tenor. Hal kedua yang belum dilakukan di dalam penelitian ini adalah menggunakan data panel, dimana responden yang sama diamati pada periode sebelum, selama dan sesudah masa pandemi 


\section{DAFTAR PUSTAKA}

Abdillah, W., \& Jogiyanto, H. (2009). Konsep dan Aplikasi PLS (Partial Least Square) untuk Penelitian Empiris.. Yogyakarta: BPFE UGM.

Adirinekso, G., Purba, J. T., Budiono, S., dan Rajagukguk, W. (2020). The Role of Price and Service Convenience on Jakarta's Consumer Purchase Decisions in Top 5 Marketplace Mediated by Consumer's Perceived Value. The 5th North America International Conference on Industrial Engineering and Operations Management (p. Retrieved from http://www.ieomsociety.org). Detroit, Michigan USA: ieomsociety.org.

Adirinekso, G. P., Purba, J. T., dan Budiono, S. (2020). Measurement of Performance, Effort, Social Influence, Facilitation, Habit and Hedonic Motives toward Pay later Application Intention: Indonesia Evidence. Proceedings of the 2nd African International Conference on Industrial Engineering and Operations Management (pp. 208 - 219). Harare, Zimbabwe: IEOM Society International.

Aileen, A., Widjaja, A., Purba, J. T., dan G, S. K. (2019). Recording application with managerial prediction features for skenoo business. IOP Conference Series: Materials Science and Engineering (pp. 508 (1), 012133). IOP.

Anderson, J. dan Gerbing, D. (1988). Structural Equation Modeling in Practice: A Review and Recommended Two Steps Approach. Physichological Bulletin, 411 - 423.

Cahyono, E. (2018, Maret 27). Revolusi Industri 4.0 dan Transformasi Organisasi Pemerintah. Retrieved from Sekretariat Kabinet Republik Indonesia: http://setkab.go.id/revolusi-industri-4-0dan-transformasi-organisasi-pemerintah/

Djaali. (2008). Psikologi Pendidikan. Jakarta: Sinar Garfika Offset.

Endarwati, O. (2017, Mei 03). Industri 4.0 Ciptakan Peluang Baru. Retrieved from Koran Sindo Sumber Referensi Terpercaya: http://koran-sindo.com/page/news/2017-0503/2/3/Industri 4 0 Ciptakan Peluang Baru

Ghozali, I. (2014). Structural Equation Modeling, Metode Alternatif dengan Partial Least Square (PLS). Edisi 4. Semarang: Badan Penerbit Universitas Diponegoro.

Hair, J. F., Risher, J., Sarstedt, M., dan Ringle, C. M. (2019, December). When to Use and How to Report The Results of PLS-SEM. European Business Review, 31(1), 2 - 24. Retrieved from 
https://www.researchgate.net/publication/329443894_When_to_use_and_how_to_report_the_res ults of PLS-SEM

Hair, J., Black, W., Babin, B., dan Anderson, R. (2014). Multivariate Data Analysis. Essex: Pearson Education Limited.

Hair, J., Hult, G., Ringle, C., dan Sarstedt, M. (2017). A primer on Partial Least Squares Structural Equation Modelling PLS-SEM. Thousand Oaks, CA : Sage.

Henseler, J., Ringle, C. M., dan Sinkovics, R. R. (2009). The Use of Partial Least Squares Path Modeling in International Marketing. Advances in International Marketing, Volume 20, , $277-$ 319.

Igen, R. (2018, April 16). Teknologi Terkini: Apa itu Industri 4.0 ? Dan apa saja elemen yang harus ada? Retrieved from Mobnasesemka.com: https://mobnasesemka.com/apa-itu-industri-4-0/

Immanuel, N. B. (2019). Consumer's Intention to Use Mobile Payment Technology: A Technology Acceptance Model Perspective. . Karawang. President University.

Kementrian Perindustrian Republik Indonesia. (2018, 03 20). Siaran Pers: Making Indonesia 4.0: Strategi RI Masuki Revolusi Industri Ke-4. Retrieved from Kementrian Perindustrian Republik Indonesia: $\quad$ http://www.kemenperin.go.id/artikel/18967/Making-Indonesia-4.0:-Strategi-RIMasuki-Revolusi-Industri-Ke-4

Kim, C. M. dan Lee, I. (2010). An empirical examination of factors influencing the intention to use mobile payment. Computers in Human Behavior, 310-322.

Kim, H.-Y. K.-S. (2018). A Study on Usage Intention of Technology-based Airlines self-service Based on UTAUT2 Model . Journal of the Korean Society for Aviation and Aeronautics , 54-63.

Kock, N. dan Hadaya, P. (2018). Minimum sample size estimation in PLS-SEM: The inverse square root and gamma-exponential methods. Information Systems Journal, 28(1), 227-261.

McDaniel Jr, C. dan Gates, R. (2015). Marketing Research. New Jersey: John Wiley \& Sons, Inc.

Monecke, A. dan Leisch, F. (2012). Structural Equation Modeling Using Partial Least Squares. Journal of Statistical Software, 1-32.

Mukminin, A., Rachman, R., dan Wahyudi, H. (2019). Penerapan Model UTAUT untuk Perilaku Pengguna "PayLater" di Dalam Traveloka. Jurnal Computech \& Bisnis, 81-90. 
Nanggala, A. Y. (2020). Use of Fintech for Payment: Approach to Technology Acceptance Model Modified. . Journal of Contemporary Information Technology, Management, and Accounting, 1 8.

Novalius, F. (2018, April 04). Economy Sektor Riil: Apa Itu Industri 4.0? Ini Penjelasan Presiden Jokowi. Retrieved from OkezoneFinance: https://economy.okezone.com/read/2018/04/04/320/1881871/apa-itu-industri-4-0-ini-penjelasanpresiden-jokowi

Nuriska, A., Asakdiyah, S., dan Setyawan, R. R. (2018). Factors Affecting Behavioral Intention in Using Go Pay with The Modified Unified Theory of Acceptance and Use of Technology 2 Model (UTAUT2) . Muhammadiyah International Journal of Economics and Business, 107 - 114.

Purba, J., Budiono, S., Rajagukguk, W., Samosir, P., dan Adirinekso, G. (2020). E-Business Services Strategy with Financial Technology: Evidence from Indonesia. 5th North American International Conference on Industrial Engineering and Operations Management. Detroit: ieomsociety.org.

Purba, J., Samuel, S., dan Purba, A. (2020). Strategic Collaboration ICT in the online Transportation Services in Jakarta Area. IOP Conference Series: Materials Science and Engineering (pp. 918, 12206). IOP.

Rajagukguk, W., Samosir, P., Purba, J. T., Budiono, S., dan Adirinekso, G. P. (2020). Dark Side of Economic Growth: A Case Study of the Relationship between Economic Growth and Suicide Mortality. The 5th North America International Conference on Industrial Engineering and Operations Management. Detroit, Michigan USA: ieomsociety.org.

Ramos, F. A. (2016). Accessing The Determinants of Behavioral Intention to Adopt Fintech Services Among the Millennial Generation. Lisboa.: Lisboa: Faculdade de Economia da Universidade Nova de Lisboa.

Shao, X. dan Siponen, M. (2011). Consumer Acceptance and Use of Information Technology: Adding consumption theory to UTAUT2. Proceedings of SIGSVC Workshop (pp. 11-157). http://sprouts.aisnet.org.

Shara, P. V. dan Widodo, T. (2018). Penerapan Model Unified Theory of Acceptance and Use of Technology (UTAUT) untuk Menganalisis Minat Pengguna Smartphone Di Kota Bandung. ResearchGate , p. 328216331. Retrieved from www.researchgate: https://www.researchgate.net/publication/328216331 
Siahaan, M. dan Legowo, N. (2019). The Citizens Acceptance Factors of Transportation Application Online in Batam: An Adaptation of the UTAUT2 Model and Information System Success Model. Journal of Theoretical and Applied Information Technology, 1666 - 1676.

Venkatesh, V., Morris, M. G., Davis, G. B. dan Davis, F. D. (2003). User Acceptance of Information Technology: Toward a Unified View. MIS Quarterly, Vol. 27, No. 3, , pp. 425-478.

Venkatesh, V., Thong, J. dan Xu, X. (2012). Consumers Acceptance and Use Information Technology : Extending The Unified Theory of Acceptance and Use of Technology. MIS Quarterly, 36(1), 157 $-178$.

Vincenzo, E. V., Chin, W. W., Henseler, J. dan Wang, H. (2010). Handbook of Partial Least Square. Hiedelberg: Springer Verlag.

Vinzi, V. E. (2010). Vinzi, V. E., Chin, W., HenseHandbook of Partial Least Squares: Concep, Methods, and Applications. Berlin Heidelberg: Springer-Verlag.

Wong, K. K.-K. (2013). Partial Least Squares Structural Equation Modeling (PLS-SEM) Techniques Using SmartPLS. Marketing Bulletin Vol 24, 1 - 32. 